\title{
2 Apple rootstock resistance to drought
}

3 Thomas Tworkoski ${ }^{\mathrm{a},}{ }^{*}$, Gennaro Fazio $^{\mathrm{b}}$, D. Michael Glenn ${ }^{\mathrm{a}}$

$4 \quad$ appalachian Fruit Research Station, ARS, USDA, Kearneysville, West Virginia, USA

$5 \quad$ blant Genetics Resources Unit, ARS, USDA, Cornell University, Geneva, New York, USA

6

*Corresponding author. E-mail address: tom.tworkoski@ars.usda.gov

\section{ABSTRACT}

8 Water for irrigation will likely be less available in apple-growing regions due to climate change

9 and competition with human needs other than agriculture. Apple cultivars and rootstocks may

10 differ in water use necessary for acceptable cropping. In two greenhouse experiments in 2014

11 and 2015 rootstocks (M.9 and MM.111) and scions ('Gala' and 'Fuji') with known differences in

12 size control and potential resistance to drought were compared under conditions of reduced water

13 availability. After 1 week without irrigation in 2014 the potting soil moisture and leaf water

14 potential $\left(\Psi_{\mathrm{L}}\right)$ were reduced more in trees on MM.111 than M.9 rootstocks and by 'Gala' than

15 'Fuji' scions. Abscisic acid (ABA) and associated metabolites dihydrophaseic acid, abscisic acid

16 glucose ester, and phaseic acid generally were greater for both scions on M.9 than MM.111.

17 Concentrations of ABA metabolites were greater in 'Gala' than 'Fuji' suggesting significant

18 metabolic rates in leaves. As noon $\Psi_{\mathrm{L}}$ decreased between -1.5 and -2.0 MPa leaf ABA levels

19 increased exponentially to concentrations above $500 \mathrm{ng} / \mathrm{g}$ dw and stomatal conductance $\left(\mathrm{g}_{\mathrm{s}}\right)$

20 decreased to less than 50 mmole $\mathrm{H}_{2} \mathrm{O} \mathrm{m}^{-2} \mathrm{~s}^{-1}$. At reduced $\mathrm{g}_{\mathrm{s}}$ carbon assimilation (A) was low but

21 greater in trees on M.9 than on MM.111. Trees grown on M.9 partitioned less dry weight (dw)

22 to roots than MM.111. However the \% dw partitioned to fine roots was greater in M.9 than 
23 MM.111 which may have helped trees grow in a small environment such as a pot. In 2015 trees

24 were grown in 45- and 75-L pots and irrigated over 3 weeks to maintain a steady $\Psi_{\mathrm{L}}$ between -

$25 \quad 1.5$ and $-2.5 \mathrm{MPa}$. This longer-term water stress in 2015 resulted in greater $\mathrm{g}_{\mathrm{s}}$ and $\mathrm{A}$ in trees on

26 MM.111 and in larger pots but WUE was still greater in trees grafted to M.9 in 3 of the 5 drought

27 dates measured. Both rootstocks provided drought resistance, but by mechanisms which appear

28 to differ and which may provide benefits to apple trees grown with reduced irrigation or with

29 water stress. The dwarfing rootstock M.9 produces higher levels of ABA that may regulate

30 stomatal opening and improve short-term drought resistance. The more invigorating rootstock

31 MM.111 may be drought hardy in the longer-term due to development of a more extensive root 32 system.

Keywords: Fruit tree, Hormone, Root system, Tree size, Water stress

\section{Introduction}

In recent years, there has been increased recognition that fruit is essential for a healthy and

balanced diet. In the future, high demand for water for consumption, recreation, industry, and agriculture will almost certainly limit water availability for irrigation of fruit trees. New tools will be needed for sustainable fruit tree production, especially with concerns about climate

41 change and the potential impact on precipitation. These tools may include trees with high water

42 use efficiency (WUE, the ratio of net carbon assimilation to evapotranspiration) and drought

43 resistant rootstocks, but mechanisms that impart water stress resistance in rootstocks are not clear

44 (Jones, 2004). Elevated levels of the hormone cis-abscisic acid (ABA) and limited hydraulic 
45 conductivity (ratio of water flow to pressure) of vascular systems have been found in some

46 dwarfing rootstocks, and these factors appear to be part of the size-controlling process (Kamboj

47 and Quinlan, 1998; Kamboj et al., 1999; Tworkoski and Fazio, 2011; Yadava and Dayton, 1972).

$48 \quad \mathrm{ABA}$ has been shown to be a root-produced message that regulates shoot dehydration resistance

49 to drying soils (Davies et al., 2005). Root-drench applications of ABA have improved drought

50 hardiness of whole apple trees (Tworkoski, et al., 2011). It is reasonable to postulate that under

51 drought stress rootstocks that produce elevated ABA may lead to water conservation processes

52 such as stomatal closure, and thus, some rootstocks used for size control of fruit tree scions may

53 also be more drought-resistant. However, increased drought resistance may have a negative

54 effect on yield. In grapes increased drought resistance often reduces yield while increasing

55 WUE (Serra et al 2013). Research is needed to identify processes or mechanisms that may

56 reduce this adverse linkage.

Rootstocks may provide drought resistance by altering processes other than stomatal

58 closure. In apple rootstocks, drought resistance has been attributed to increased hydraulic

59 conductance, recovery from embolisms in the xylem, and shift in assimilate partitioning to root

60 growth (Atkinson et al., 1999; Bauerle et al., 2011; Cohen et al., 2007). Hydraulic conductance

61 was $66 \%$ more in 'Gala' than 'Fuji' stems on any rootstock (Tworkoski and Fazio 2015a). Liu et

62 al. (2012) found that 'Gala' had improved WUE when grafted to drought resistant apple

63 rootstocks. In contrast to dwarfing rootstocks high vigor rootstocks displayed resistance to

64 drought by increased assimilate partitioned to root development that increased the volume of soil

65 accessible to roots for water uptake (Bauerle et al., 2011). Drought resistance may be further

66 complicated by the effect that scion vigor can have on rootstock root growth and rootstock

67 capacity for drought resistance (Tworkoski and Fazio 2015b). More work is needed to 
understand the nature of root/shoot signals (e.g. ABA and related metabolites) and potential benefits of rootstock/high WUE scion combinations to develop technologies that are adapted to water stress. Improved understanding of root-to-shoot signals that may differ among rootstocks and affect drought hardiness will assist in the selection of rootstocks needed for efficient and sustainable production systems in apple.

The objective of our experiment was to determine whether two cultivars develop different water use strategies that may elevate resistance to water stress when they are grown on rootstocks with large vs. small root systems or rootstocks that have induced or constitutively high ABA. We hypothesized that: (1)Under well-watered conditions there are no differences in leaf water potential $\left(\Psi_{\mathrm{L}}\right)$ and carbon assimilation $(\mathrm{A})$ of scions grafted to M.9 and MM.111 ( 35 and $70 \%$ height of seedling, respectively). (2)Under drying conditions a vigorous rootstock (MM.111) maintains $\Psi_{\mathrm{L}}$ and A with its large root system that can access larger soil volumes. (3)Alternatively, under drying conditions M.9 rootstock physiologically maintains favorable water status by modulating stomatal conductance $\left(\mathrm{g}_{\mathrm{s}}\right)$ with ABA production.

\section{Materials and Methods}

\subsection{Trees}

Trees were purchased from Stark Brothers Nursery (Louisiana, MO) in March 2014 and planted in 35 liter (L) pots with potting soil (Metromix 360/fine sand, 2.8/1, v/v) at the

Appalachian Fruit Research Station. Scion-rootstock combinations included 'Gala' and 'Fuji' on M.9 and MM.111. Trees were approximately $1 \mathrm{~m}$ tall and $15.8 \mathrm{~mm}$ in diameter. During the 
89 growing season, trees in the greenhouse were fertilized $(1.75 \mathrm{~g}$ of $20 \mathrm{~N}-8.8 \mathrm{P}-16.6 \mathrm{~K} \mathrm{w} / \mathrm{w} / \mathrm{w}$ per

tree) on a weekly basis.

In March 2015 another group of trees from Stark Brothers Nursery with similar dimensions of the 2014 trees were planted in either $45 \mathrm{~L}$ or $75 \mathrm{~L}$ pots and water was withheld beginning in May 2015. In both 2014 and 2015 all pots were covered with aluminum foil and plastic sheet to reduce evaporation from the potting soil. It was assumed that water loss measured gravimetrically was due to evapotranspiration. In both years the trees were lightly pruned to a modified central leader.

\subsection{Water}

Three months after planting in June 2014 water was withheld from half the trees (drought) and the other half received water every day (controls). Water was withheld from 1 to 7 days and reapplied from 7 to 14 days. Plant moisture status was measured with three mature leaves from the top, middle, and lower canopy of each tree on 1, 4, 7, and 14 days. Predawn and noon $\Psi_{\mathrm{L}}$ were measured with a pressure chamber (Soil Moisture Equipment Corp., Santa Barbara, Calif.). Each leaf was covered and cut, and water potential was measured. Water was reapplied when wilt was evident or $-2.5 \mathrm{MPa} \Psi_{\mathrm{L}}$ was reached, approximately 8 days from the time of withholding. The three leaves used for measuring water status were pooled, quickly frozen in liquid $\mathrm{N}_{2}$, lyophilized and analyzed for ABA and related metabolites. Rate of leaf water potential decrease was used as an index of stress.

Moisture content (MC) of the potting soil at 1, 4, 7, 8, and 14 days was measured by collecting potting soil from the side of the pot with a probe half the distance from the top to the 
110 bottom of the pot. Watering all trees resumed after 8 days. The soil was weighed immediately

111 for fresh weight (fw) and after 7 days drying at $80 \mathrm{C}$ for dry weight (dw).

$$
\operatorname{MC}(\%)=((\mathrm{fw}-\mathrm{dw}) / \mathrm{dw}) \times 100
$$

114 water was withheld for 14 days until $\Psi_{\mathrm{L}}$ at dawn was approximately $-1.0 \mathrm{MPa}$ and at noon was

115 approximately -2.5 MPa. Significant plant stress occurs as water potential approaches $-1.5 \mathrm{MPa}$

116 (Fitter and Hay 1987). Daily water use was measured gravimetrically by measuring the change

117 in mass of the tree and the pot and from soil cores. Control trees continued to receive full

118 watering while drought trees received daily water that decreased over time. After 14 days

119 without watering drought trees daily watering was then reduced every 3 days by 20, 40, and 60\%

120 of the daily water use, approximately $0.879,0.659$, and $0.439 \mathrm{~L} /$ day for the $45-\mathrm{L}$ pots and 1.174 ,

1210.880 , and $0.587 \mathrm{~L} /$ day for $75-\mathrm{L}$ pots, respectively.

\subsection{Growth and physiological measurements}

In 2014 trees were measured for early morning and midday stomatal conductance $\left(\mathrm{g}_{\mathrm{s}}\right)$,

124 evapotranspiration (E), and carbon assimilation (A) of three mature leaves per tree (CIRAS-3; PP

125 Systems, Haverhill, Mass.) on 1, 4, 7, 8, and 14 days after drought was initiated. Water use

126 efficiency (WUE) was calculated as A / E:

127 WUE $=$ Net $\mathrm{CO}_{2}$ assimilation rate $\left(\mu \mathrm{mol} \mathrm{m} \mathrm{s}^{-1}\right) /$ Evapotranspiration rate $\left(\mathrm{mmol} \mathrm{H}_{2} \mathrm{O} \mathrm{m}^{-2} \mathrm{~s}^{-1}\right)$

After the final (14 days) gas exchange measurements, trees were harvested and dw was 
131 of leaves from 5 trees of each scion/rootstock combination and a regression was developed to

132 estimate LA based on leaf number (leaf area per tree $=(16.86 *$ leaf number per tree $)+1116.4 ; \mathrm{r}^{2}$

$133=0.88)$.

In 2015 trees were maintained in a drought state (-1.5 MPa or lower) for 3 wks.

135 Substantial plant stress occurs as water potential approaches -1.5 MPa (Fitter and Hay 1987).

136 Dawn and noon $\Psi_{\mathrm{L}}$ was measured daily. Assimilation, $\mathrm{g}_{\mathrm{s}}, \mathrm{E}$ at noon was measured and potting

137 soil relative water content was measured twice per week.

138 In 2015 the root system adaptation to drought stress was calculated as the apparent root surface 139 water potential (ARSWP, Jones, 1983):

$$
\Psi_{\mathrm{s}(\mathrm{D})}=\Psi_{1(\mathrm{D})-} \Psi_{1(\mathrm{C})}\left[\mathrm{g}_{\mathrm{s}(\mathrm{D})} / \mathrm{g}_{\mathrm{s}(\mathrm{C})}\right]\left[\mathrm{LA}_{(\mathrm{D})} / \mathrm{LA}_{(\mathrm{C})}\right]
$$

141 Where:

$142 \Psi_{\mathrm{S}(\mathrm{D})}=$ the apparent water potential at the root surface of the stressed treatment relative to the 143 non-stressed treatment $(\mathrm{MPa}), \Psi_{1(\mathrm{D})}=$ leaf water potential of the stressed treatment $(\mathrm{MPa}), \Psi_{1(\mathrm{C})}=$ 144 leaf water potential of the non-stressed $(\mathrm{MPa})$ treatment, $\mathrm{g}_{\mathrm{s}(\mathrm{D})}=$ stomatal conductance of the 145 stressed treatment $\left(\mathrm{sm}^{-1}\right), \mathrm{g}_{\mathrm{s}(\mathrm{C})}=$ stomatal conductance of the non-stressed treatment $\left(\mathrm{sm}^{-1}\right)$, $146 \mathrm{LA}_{(\mathrm{D})}=$ leaf area of the stressed treatment, and $\mathrm{LA}_{(\mathrm{C})}=$ leaf area of the non-stressed treatment. 147 The $A_{(D)}$ and $A_{(C)}$ are leaf area estimates based on regression equations between leaf number and 148 leaf area. The ARSWP is an indirect measure of soil water potential at the root surface.

149 ARSWP provides an estimate of soil water conditions when trees are transpiring during the day 150 and but not pre-dawn (Jones 1983) 


\subsection{Hormone Analysis}

In 2014 abscisic acid was measured in leaves of all scion-rootstock combinations at 1, 4, 7, 8, and 14 days after withholding water using methods described previously (Tworkoski and Fazio 2015b). ABA and metabolites dihydrophaseic acid (DPA), abscisic acid glucose ester (ABAGE), phaseic acid (PA) were measured (National Research Council, Plant Biotechnology Institute, 110 Gymnasium Place, Saskatoon, Saskatchewan, S7N0W9). Briefly, samples were extracted in isopropanol:water:glacial acetic acid $(80: 19: 1, \mathrm{v} / \mathrm{v} / \mathrm{v})$ that was spiked with stable isotopes of each hormone, dried, reconstituted in acidified methanol, partitioned with hexane, and the aqueous phase was then dried. Residue was reconstituted in acidified methanol, loaded on a C18 column, and the eluate was dried. Residue was reconstituted in acidified $40 \%$ methanol (v/v) and injected in an HPLC ESI-MS/MS (Chiwocha et al. 2003, Chiwocha et al. 2005). Individual hormones were quantified based upon the peak area of the native hormone and corrected for loss based on recovery of the internal standard (Ross et al. 2004). The limit of quantitation was established where the signal-to-noise ratio dropped below 8 .

\subsection{Experimental design}

In both 2014 and 2015, the experimental designs were completely randomized. There were 5 and 3 whole-tree replications for greenhouse growth measurements during the drought experiments in 2014 and 2015, respectively. Main effects of scion, rootstock, and also pot size (2015 only) during the drought were analyzed by SAS Proc GLM followed by Duncan's New Multiple Range Test. Scion, rootstock, and their interaction were the main effects in the 
175 analysis. Relationships among continuous variables were tested by Proc Corr and Proc Reg in 176 SAS. All statistical tests were considered significant if the $\mathrm{P}>\mathrm{f}$ was at the 0.05 level or lower 177 (SAS Institute, Inc. 2003. The SAS system for Windows. Release 9.1. SAS Inst. Inc., Cary, NC 178 27513).

\section{Results}

Interactive effects of scion and rootstock on potting soil moisture were found on days 1

and 4. Potting soil moisture was 25, 25, and $12 \%$ lower in 'Fuji' trees grown on MM.111 than M.9 at 1, 4, and 7 days without irrigation (Fig. 1). Larger potting soil moisture reductions were 184 also observed in 'Gala' on MM.111 compared with 'Gala' on M.9 on day 4. Scions and 185 rootstocks differentially affected soil moisture under drought conditions. Soil moisture was depleted more by 'Gala' compared to 'Fuji' over both rootstocks by day 7.

In 2014 pre-dawn $\Psi_{\mathrm{L}}$ was lower in 'Fuji' on M.9 than on MM.111 on days 1, 4 and 7

(Fig. 2). At noon the trees without water for 4 and 7 days had $\Psi_{\mathrm{L}}$ 's of -2 to $-2.5 \mathrm{MPa}$ and there were no treatment differences (Fig. 2). In 2014 dawn water content of potting soil above approximately $75 \%$ did not markedly affect $\Psi_{\mathrm{L}}$ (Fig. 3). Above $75 \%$ potting soil moisture content $\Psi_{\mathrm{L}}$ at dawn was less than -0.5 MPa. However, at noon $\Psi_{\mathrm{L}}$ of some trees at the same

192 potting soil water content had a more negative $\Psi_{\mathrm{L}}$. The $\Psi_{\mathrm{L}}$ changed quantitatively during 193 drought but the $\Psi_{\mathrm{L}}$ among the different scion-rootstock combinations were relatively unchanged 194 at the noon sampling (Fig. 2B). 
197 For example 'Fuji' on M.9 had consistently more soil moisture and lower dawn $\Psi_{\mathrm{L}}$ than 'Gala' on MM.111 (Figs. 1 and 2). Noon $\Psi_{\mathrm{L}}$ tended to show a similar relationship between 'Fuji' on M.9 and 'Gala' on MM.111 but differences were not significant.

At dawn 4 days without water, Gala and Fuji had less negative $\Psi_{L}$ on M.9 than on

201

202

203

204 216 'Fuji'.
In well-watered potting soil (control) leaf ABA was not consistently different between scions and rootstocks (data not shown). However, under drought conditions leaf ABA concentrations were affected by rootstock and time without water (Fig. 4). Under drought stress ABA levels in leaves were generally higher, although not always significantly, for either cultivar on a M.9 than a MM.111 rootstock (Fig. 4). ABA levels in cultivars were inconsistent at 7 and 8 days without water and differences were numerically but not statistically different: higher in 'Fuji' than 'Gala' on M.9 but the opposite on MM.111.

The conjugate (ABAGE) and degradation metabolites PA and DPA were affected by both scion and rootstock but differences were not statistically significant (Fig. 4). Within a scion ABAGE concentrations always were greater on M.9 than on MM.111 rootstocks under drought conditions. Unlike ABA, ABAGE tended to be greater under drought conditions in 'Gala' than

$\mathrm{G}_{\mathrm{s}}$ and $\mathrm{E}$ at dawn were quantitatively lower than at noon but treatment effects were relatively the same (data not presented). Consequentially, only noon results are presented (Table 
219 1). During the time between 4 and 7 days without water drought-treated trees reduced $g_{s}$ (Table

220 1). $G_{\mathrm{s}}$ measured at noon were significantly higher in MM.111 for days 7 and 14 without water.

221 Reduced $\mathrm{g}_{\mathrm{s}}$ coincided with drying soils, higher ABA concentrations, and lower $\Psi_{\mathrm{L}}$ (Figs. 1, 3,

222 and 4). Evapotranspiration was not consistently affected by scion or rootstock. At day $1 \mathrm{E}$ was

223 higher in trees grown on M.9 than on MM.111. However, as drought progressed E was greater

224 in MM.111 than M.9 (Table 1).

Assimilation at dawn and noon decreased with time without water (Fig. 5). Trees with

226 M.9 rootstocks maintained numerically, if not statistically greater assimilation as drought

227 increased from 1 to 7 days without water.

As $\Psi_{\mathrm{L}}$ at noon became more negative $\mathrm{ABA}$ concentrations increased and reduced

229 stomatal conductance coincided with increased ABA concentrations (Fig. 6).

230 At 4 and 7 days without water and during the following period with daily watering (14 days) the

231 water use efficiency (WUE) was significantly greater in scions grafted to M.9 than to MM.111

232 (Table 2). Assimilation was generally higher on trees grafted to M.9 rootstocks. Reduced

233 evapotranspiration of trees on M.9 rootstock at 7 and 14 without water may also have contributed

234 to greater WUE (Table 2).

Dry weight distribution was affected by scion and rootstock but not by the watering treatment (Tables 3 and 4). More dw partitioned to leaf in 'Gala' than 'Fuji' regardless of

237 rootstock. 'Fuji' on MM.111 had significantly more dw partitioned to roots than to leaves as 238 illustrated by the root-to-leaf ratio that was at least two-times greater than other scion-rootstock 239 combinations (Table 4). Both cultivars tended to have less biomass partitioned to roots when 240 grafted to M.9 but M.9 rootstocks tended to have more fine roots (Table 3). Dry weight 
241 distribution might be altered with a more prolonged drought rather than the 1-week drought that 242 was used in this study.

In the 2015 study the effects of scion, rootstock, and pot volume on physiological

244 variables were determined during the controlled and persistent drought (Tables 5, 6, 7, and 8).

245 Rootstock and pot volume affected $\mathrm{g}_{\mathrm{s}}$, and A with MM.111 and 75 L pot volume generally being

246 greater (Tables 5 and 6). A significant scion-rootstock interaction affected $\mathrm{g}_{\mathrm{s}}$ on days 14 and 24

247 (Table 5). On day $14 \mathrm{gs}_{\mathrm{s}}$ was $162 \%$ higher for 'Fuji' on MM.111 than on M.9 compared with

248 'Gala' that was approximately 383\% higher on MM.111 than on M.9. On day 24 'Fuji had $61 \%$

249 the $\mathrm{g}_{\mathrm{s}}$ on MM.111 than on M.9 and 'Gala' $\mathrm{g}_{\mathrm{s}}$ on MM.111 was $109 \%$ higher than on M.9. On day

25014 A was $117 \%$ higher for 'Fuji' on MM.111 than on M.9 compared with 'Gala' that was

251 approximately $211 \%$ higher on MM.111 than on M.9. On day 35 'Fuji' on MM.111 had $42 \%$ the

252 A than on M.9 and 'Gala' on MM.111 was 327\% higher than on M.9. As drought proceeded it

253 appears that 'Fuji' maintained higher gs and A on M.9 than on MM.111. 'Gala' maintained

254 higher $\mathrm{g}_{\mathrm{s}}$ and A on MM.111 at all stages of drought.

WUE was greater in M.9 than MM.111 on days 14 and 28 and was affected by pot

256 volume on days 17 and 35 (Table 7). Scion-rootstock and scion-pot volume were significant on

257 days 17 and 28. On day 17 WUE was $87 \%$ for 'Fuji' on MM.111 than on M.9 compared with

258 'Gala' that was approximately $153 \%$ higher comparing the same rootstocks. On day 28 'Fuji' on

259 MM.111 had 51\% the WUE than on M.9 and 'Gala' on MM.111 was 128\% higher than on M.9.

260 The $\Psi_{\mathrm{L}}$ during the drought, as expected, was usually higher in trees grown $45 \mathrm{~L}$ than $75 \mathrm{~L}$ pot

261 volumes (Table 8). Significant interactions of scion and rootstocks occurred on days 17 and 28;

262 scion by pot volume interaction was significant on days 24 and 35 . On day $24 \Psi_{\mathrm{L} \text { of }}$ 'Fuji' on M.9 
263 was $74 \%$ in a $75 \mathrm{~L}$ pot compared to being in a $45 \mathrm{~L}$ pot. $\Psi_{\mathrm{L} \text { of }}$ 'Gala' on M.9 was approximately

$26495 \%$ in a $75 \mathrm{~L}$ pot compared to being in a $45 \mathrm{~L}$ pot. On day $35 \Psi_{\mathrm{L}}$ was $98 \%$ that for 'Fuji' on M.9

265 in a $75 \mathrm{~L}$ pot compared to being in a $45 \mathrm{~L}$ pot. 'Gala' $\Psi_{\mathrm{L}}$ was $117 \%$ comparing $75 \mathrm{~L}$ to being in a

266 45L pot.

267 Scion also affected WUE and $\Psi_{\mathrm{L}}$ but only on days 17 and 24. In general, trees grown on

268 M.9 or in $45 \mathrm{~L}$ soil volumes were most water stressed (more negative MPa) and had lower gs and

269 A. Although not always significant, trees on MM.111 more often maintained a less negative

270 ARSWP than did trees on M.9 (Table 9).

271 Pot volume strongly affected physiological parameters in 2015 (Tables 5-8). However

272 pot volume had few interactions with scion or rootstock. On day $24 \Psi_{\mathrm{L}}$ was $74 \%$ that for 'Fuji'

273 on M.9 in a 75L pot compared to being in a 45L pot. In 'Gala' on M.9 $\Psi_{\mathrm{L}}$ was approximately

$27495 \%$ in a $75 \mathrm{~L}$ pot compared to being in a 45L pot. On day $35 \Psi_{\mathrm{L}}$ was $98 \%$ that for 'Fuji' on M.9

275 in a $75 \mathrm{~L}$ pot compared to being in a $45 \mathrm{~L}$ pot. 'Gala' $\Psi_{\mathrm{L}}$ was $117 \%$ comparing $75 \mathrm{~L}$ to being in a

276 45L pot.

277

278 4. Discussion

279

Water conservation is increasingly important to orchardists as the human population and

280 associated activities demand more water from fixed or dwindling sources. New technologies and

281 creative uses of existing technologies can help meet grower needs. Apple rootstocks have long

282 been used to regulate size of scion and some rootstocks may avoid adverse dehydration by

283 exploiting water sources within soil or by using water efficiently. 
Water use was greater by 'Gala' than 'Fuji' trees and by trees on MM.111 than M.9

285 rootstocks (Fig. 1). Leaf water potential $\left(\Psi_{\mathrm{L}}\right)$ is an index of tree water status and $\Psi_{\mathrm{L}}$ changes reflected the depletion of potting soil water by trees (Fig. 2). $\Psi_{\mathrm{L}}$ declined (became more negative) more quickly in trees grafted to MM.111 than M.9. To determine the impact of the reduced water usage physiological processes such as carbon assimilation were measured.

Capacity for carbon assimilation (A) was greater in 'Fuji' trees and either cultivar grown on M.9 rootstocks when measured at dawn (Fig. 5). At noon these differences were much smaller but still apparent. It is likely that greater water use efficiency (WUE) of trees grown on M.9 rootstocks was due, at least in part, to higher A associated with M.9 under water stress conditions.

All scion-rootstock combinations responded to drought over time with lower (more negative) $\Psi_{\mathrm{L}}$ (Fig. 2). Over time, $\Psi_{\mathrm{L}}$ decreased more quickly at noon than dawn. At dawn $\Psi_{\mathrm{L}}$ 's were similar between 0 and 4 days, reflecting little water stress. In contrast, noon $\Psi_{\mathrm{L}}$ decreased rapidly by day 4 and remained low between 4 and 7 days. It is possible that the trees were able to recover sufficient water overnight to reduce tree water deficits by dawn but the water was insufficient to overcome noon deficits. Tree mechanisms which enhance water stress resistance include reduced stomatal conductance of water vapor. Other resistance mechanisms may reduce water loss with efficient or extensive root systems that enhance water uptake.

Trees on MM.111 had lower $\Psi_{\mathrm{L}}$ even though more dw was partitioned to roots than trees on M.9 (Fig. 2 and Table 3). In the 2014 study large root systems may not have provided drought resistance. By growing all trees in the same-size (35 L) pot, trees grown on MM.111 rootstocks were larger than trees on M.9 and water use over time was greater. However, in the 
field trees with larger root systems (i.e. MM.111) may exploit larger soil volumes to avoid dehydration stress. Indeed during the 2015 experiment trees grown in the $75 \mathrm{~L}$ soil volume had greater $\mathrm{g}_{\mathrm{s}}$ and greater $\mathrm{A}$ than trees in the smaller, 45L volume (Tables 5 and 6).

Dry weight distribution within a rootstock (i.e. fine vs. coarse roots) may also affect drought resistance. The greater allocation of dw to fine roots in M.9 than MM.111 may have enabled exploitation of water from soil (Table 3). In ungrafted rootstocks grown with reduced irrigation, M.9 produced fewer coarse ( $>3 \mathrm{~mm}$ diameter $)$ and more fine roots $(<3 \mathrm{~mm}$ diameter $)$ under drought conditions (Atkinson et al. 1999). Neither coarse nor fine roots differed in MM.111 trees that were grown in well-watered or drought conditions.

Reduced stomatal conductance is a mechanism of water conservation that provides avoidance of adverse effects of drought. Under drying conditions a root-generated message, ABA, may translocate to leaves where it can stimulate stomatal closure (Davies 2005). As soil dried $\Psi_{\mathrm{L}}$ decreased and leaf ABA concentrations increased (Figs. 2 and 4). An inflection point for the rate of change of ABA leaf concentrations was observed (Fig. 6). As $\Psi_{\mathrm{L}}$ decreased below -1.5 $\mathrm{MPa}$ leaf $\mathrm{ABA}$ concentrations increased more rapidly. The rate of ABA concentration increase was more rapid for trees on M.9 than MM.111 rootstocks. However, $\mathrm{g}_{\mathrm{s}}$ of trees on M.9 rootstocks continued, albeit at a reduced rate, at elevated leaf ABA concentrations (Fig. 6 bottom). Scions on M.9 rootstock tended to have more negative ARSWP, suggesting the root was drawing more water to maintain $\Psi_{\mathrm{L}}$ which under drought had reduced $\mathrm{g}_{\mathrm{s}}$ and A (Table 9). Continued $g_{s}$ at reduced $\Psi_{\mathrm{L}}$ may allow assimilation (A) and evapotranspiration to continue at reduced levels which may explain greater WUE of scions grown on M.9 than MM.111 (Tables 2, 3, and Fig. 5). At 35 days with drought the ARSWP approached zero possibly due to reduced $\mathrm{g}_{\mathrm{s}}$ of drought trees (Tables 5 and 9). 

rootstocks (Fig. 4). PA and DPA were also higher in leaves of scion grafted to M.9 than to MM.111. Kondo et al. (2014) suggested that in apple reduced catabolism of ABA may improve drought resistance by preserving ABA-induced closure of stomates. In the current study, elevated concentrations of PA and DPA in 'Gala' and M.9 suggest that significant metabolic 334 activity may be ongoing that controls even higher levels of ABA from developing (Fig. 4). 335 Exogenous applications of ABA can result in leaf senescence (Tworkoski et al. 2011). It is 336 possible that excessively high levels of endogenous ABA may contribute to leaf drop which may 337 improve chances for tree survival at the cost of current-year growth and reproduction.

In some studies dwarfing rootstocks have been found to be less susceptible to dehydration than vigorous rootstocks. More vigorous rootstocks such as M.26 and MM.111 had higher $g_{s}$ and lower $\Psi_{L}$ than dwarfing rootstocks such as M.27 during severe drought (Atkinson 341 et al. 2000). Reduced $g_{s}$ is generally considered a short-term adaptation to avoid drought stress.

342 Elevated sensitivity of MM.111 to drought may also be associated with retention of leaves 343 (Atkinson et al. 1999). Based on weight loss of potted trees, 'Imperial Gala' on M.9 was less 344 sensitive to drought than on MM.111 (Fernandez et al. 1997). In contrast other research found 345 that the invigorating rootstock, MM.111, has been more resistant to dehydration. Anecdotally 346 M.27, G.11, and G.30 are very susceptible, M.9 and M.26 are moderately susceptible, and M.7 347 and MM.111 have low susceptibility to drought stress 348 (https://web.extension.illinois.edu/mms/downloads/47281.pdf). Our experiment in 2015 349 supports the idea that more vigorous rootstocks may be less susceptible to drought stress when 350 trees are grown in large soil volumes with homogeneous water distribution. In the field intraand inter-specific root competition and site conditions may also affect drought tolerance. 
Dwarfing rootstocks may be advantageous when trees are grown in drier or well-drained soil. 'Cox's Orange Pippin' on M.9 had higher yield / $\mathrm{m}^{2}$ than more vigorous rootstocks on 355 sand; the opposite was found on loam (Preston 1959). Our results agree with Fernandez et al. 356 (1997) that ABA was higher in leaves of drought-stressed apple trees grown on M.9 EMLA than 357 on more vigorous rootstocks, possibly due to reduced evapotranspiration. The provenance of apple germplasm can affect drought resistance. Species of Malus that 359 originated from dry environments responded to drought with higher levels of ABA and improved 360 WUE (Ma 2008). However, species originating from well-watered environments did not 361 respond with elevated ABA. Within a species differences in genetically-based ABA metabolism 362 can significantly alter and promote plant adaptation to drought (Mahajan and Tuteja, 2005).

363 Markers for elevated ABA or extensive root systems may assist in searching for and developing 364 rootstocks that could be targeted for use in specific growing environments, such as dry areas 365 where little irrigation may be available. Age and stage of tree development may influence the capacity for drought resistance.

367 Massonnet et al. (2007) found 'Braeburn' to be more water-conserving than 'Fuji'. They 368 suggested that stomatal conductance (i.e. functional components) and canopy architecture (i.e. 369 structural components) could be complementary when selecting drought-resistant apple trees. 370 However, structural components and functional components become more diverse as trees 371 mature. The complexity of apple tree development over time can produce challenges for 372 understanding and selecting apple rootstocks that are drought resistant (Nabi et al. 2000). We 373 worked with rootstocks that may affect both functional and structural components of scion.

374 Results support the following hypotheses: 1)Under moist conditions there are no differences 
375 between M9 \& MM111 in $\Psi_{\mathrm{L}}, \mathrm{A}$, and $\mathrm{g}_{\mathrm{s}}$. 2)Under drying conditions MM111 maintains its water 376 potential and gas exchange with its large root system. 3)The M9 rootstock physiologically

377 maintains water status by modulating stomatal conductance with ABA production.

378 A number of plant adjustments can occur in response to limited water availability. In this 379 paper we have addressed only a few of these adaptations to drought and other mechanisms to 380 improve drought resistance remain to be addressed. Short-term or rapid adjustments to prevent 381 dehydration include reduced stomatal aperture, hydraulic conductivity, and leaf angle. Long382 term adjustments include reduced leaf area or increased biomass distribution to the root.

383 Dwarfing rootstocks such as M.9 may elevate leaf concentrations of proline and soluble sugars 384 that modify osmotic potential and improve drought hardiness (Alizadeh et al. 2011).

Potential feedback loops between scion and rootstock may exist and affect drought 386 resistance. Atkinson (1980) observed that scions may affect rootstock growth and function, e.g. 387 by affecting available carbohydrates, stomatal density, and WUE - which may be affected by 388 both scion and rootstock. The potential confounding effects that some scions may have when 389 grafted on rootstock deserves scrutiny. Drought resistance may improve WUE and tree survival 390 but it may also be associated with yield loss (Serra et al 2013). Soil water content necessary to 391 avoid loss of yield or fruit quality differs among cultivars as well as rootstocks (Braun et al. 392 1989, Jones 2004).

\section{Conclusion}

In apple, long-term resistance to drought may be associated with vigorous root systems

395 that can exploit soil whereas short-term adaptations may benefit from root signals that are 396 sensitive to drying conditions. If these hypotheses prove to have merit then breeders may 
397 identify the gene(s) associated with elevated ABA in rootstocks such as M.9 and include it into 398 the genome of rootstocks with robust root systems such as MM.111 to attain multiple forms of 399 drought protection.

400

401 Acknowledgements

402

403

404

405

406

407 opportunity provider and employer.

408

409 References

410 Atkinson, C. J., Policarpo, M., Webster, A.D., A.M. Kuden. 1999. Drought tolerance of apple rootstocks: Production and partitioning of dry matter. Plant and Soil. 206, 223-235.

412 Atkinson, C. J., Policarpo, M., Webster, A.D., Kingswell, G. 2000. Drought tolerance of clonal Malus determined from measurements of stomatal conductance and leaf water potential.

415 Bauerle T. L., Centinari, M., Bauerle, W.L. 2011. Shifts in xylem vessel diameter and embolisms in grafted apple trees of differing rootstock growth potential in response to drought. Planta. 234, 1045-1054. 
Braun, P., Aspinall, D. , Lenz, F. 1989. The use of physiological indicators of water status in irrigation scheduling in citrus. Acta Hort. 240, 267-270.

Jones, H.G. 2004. Irrigation scheduling: Advantages and pitfalls of plant-based methods. J. Expt. Bot. 55, 2427-2436. doi:10.1093/jxb/erh213.

Chiwocha S.D.S., Abrams S.R., Ambrose S.J., Cutler A.J., Loewen M., Ross A.R.S., Kermode A.R. 2003. A method for profiling classes of plant hormones and their metabolites using liquid chromatography-electrospray ionization tandem mass spectrometry: analysis of hormone regulation of thermodormancy of lettuce (Lactuca sativa L.) seeds. Plant J. $35,405-417$.

Chiwocha, S.D.S., Cutler A.J., Abrams S.R., Ambrose S.J., Yang J., Ross A.R.S., Kermode A.R. 2005. The etr-2 mutation in Arabidopsis thaliana affects the abscisic acid, auxin, cytokinin and gibberellin metabolic pathways during maintenance of seed dormancy, moist-chilling and germination. Plant J. 42, 35-48.

Cohen, S., Naor, A., Bennink, J., Grava, A., Tyree M. 2007. Hydraulic resistance components of mature apple trees on rootstocks of different vigours. J. Expt. Bot. 58, 4213-4224.

Davies, W.J., Kudoyarova, G., Hartung W. 2005. Long-distance ABA signaling and its relation to other signaling pathways in the detection of soil drying and the mediation of the plant's response to drought. J. Plant Growth Regul. 24, 285-295.

Fernandez, T. R., Perry, R.L., Flore, J.A. 1997. Drought response of young apple trees on three rootstocks. II. Gas exchange, chlorophyll fluorescence, water relations, and leaf abscisic acid. J. Amer. Soc. Hort. Sci. 122,841-848. 
Glenn, D.M., Welker W.V. 1993. Water transfer diminishes root competition between peach and tall fescue. J. Amer. Soc. Hort. Sci. 118, 570-574.

Jones, H.G. 1983. Estimation of an effective soil water potential at the root surface of transpiring plants. Plant, Cell \& Environ. 6, 671-674.

Jones H. G. 2004 Irrigation scheduling: advantages and pitfalls of plant-based methods. J. Expt. Bot. 55, 2427-2436.

Hartung W., Sauter A., Hose E. 2002. Abscisic acid in the xylem: where does it come from, where does it go? J. Expt. Bot. 53, 27-32.

Kondo, S., Sugaya, S., Kittikorn, M., Todoroki, Y., Mizutani, M., Hirai, N. 2014. Dehydration tolerance in apple seedlings is advanced by retarding ABA 8'-hydroxylase CYP707A. Acta Hort. 1042, 151-157.

Kamboj, J.S., Quinlan, J.D. 1998. The apple rootstock and its influence on endogenous hormones. In: VII International Symposium on Plant Bioregulation in Fruit Production, Valenca, Spain. Acta Hort. 463, 143-152.

Kamboj, J.S., Browning, G., Blake, P.S., Quinlan, J.D., Baker D.A. 1999. GC-MS-SIM analysis of abscisic acid and indole-3-acetic acid in shoot bark of apple rootstocks. Plant Growth Regul. 28, 21-27. 
Liu, B.H., Cheng, L., Liang, D., Zou, Y.J., Ma, F.W. 2012. Growth, gas exchange, water-use efficiency, and carbon isotope composition of 'Gale Gala' apple trees grafted onto 9 wild Chinese rootstocks in response to drought stress. Photosynthetica. 50, 401-410.

Ma X., Ma F., Mi Y., Ma Y., Shu H. 2008. Morphological and physiological responses of two contrasting Malus species to exogenous abscisic acid application. Plant Growth Regul. $56,77-87$.

Mahajan, S., Tuteja, N. 2005. Cold, salinity and drought stresses: an overview. Arch. Biochem. and Biophys. 444, 139-158.

Ross A.R.S., Ambrose S.J., Cutler A.J., Feurtado J.A., Kermode A.R., Nelson K., Zhou R., Abrams S.R. 2004. Determination of endogenous and supplied deuterated abscisic acid in plant tissues by high performance liquid chromatography-electrospray ionization tandem mass spectrometry with multiple reaction monitoring. Anal. Biochem. 329, 324-333.

Naor, A., Klein, I., Doron, I. 1995. Stem Water Potential and Apple Size. J. Amer. Soc. Hort. Sci. $120,577-582$.

SAS Institute, Inc. 2001. The SAS system for Windows. Release 8.02. SAS Inst. Inc., Cary, NC.

Serra, A., Strever, P., Myburgh, A., Deloire, A. 2014. Review: the interaction between rootstocks and cultivars (Vitis vinifera L.) to enhance drought tolerance in grapevine. Austral. J. Grape and Wine Res. 20, 1-14. 
483 Tworkoski, T., Fazio, G. 2011. Physiological and morphological effects of size-controlling 484 rootstocks on 'Fuji' apple scions. Acta Hort. 903, 865-872.

485

486 Tworkoski, T., Fazio, G. 2015a. Effects of size-controlling apple rootstocks on growth, abscisic 487 acid, and hydraulic conductivity of scion of different vigor. International J. Fruit Sci.

488 DOI: $10.1080 / 15538362.2015 .1009973$.

489

490 Tworkoski, T., Fazio, G. 2015b. Hormone and growth interactions of scions and size-controlling 491 rootstocks of young apple trees. Plant Growth Regul. DOI 10.1007/s10725-015-0078-2.

492

493 Tworkoski T., Wisniewski, M., Artlip, T. 2011. Application of BABA and s-ABA for drought 494 resistance in apple. J. App. Hort. 13(2), 85-90.

495

496 Yadava, U.L., Dayton, D.F. 1972. The relation of endogenous abscisic acid to the dwarfing 497 capability of East Malling apple rootstocks. J. Amer. Soc. Hort. Sci. 97, 701-705. 
Table 1.

Main Effects of two scions ('Fuji' and 'Gala') and two rootstocks (M.9 and MM.111) during drought on stomatal conductance and transpiration measured in the greenhouse during 2014 at noon under drought conditions increasing with time.

\begin{tabular}{|c|c|c|c|c|}
\hline \multirow[t]{3}{*}{ Treatments } & \multicolumn{4}{|c|}{ Days $^{1}$} \\
\hline & 1 & 4 & 7 & 14 \\
\hline & \multicolumn{4}{|c|}{ Stomatal conductance $\left(\mathrm{mmol} \mathrm{H} \mathrm{H}_{2} \mathrm{O}^{-2} \mathrm{~s}^{-1}\right)$} \\
\hline \multicolumn{5}{|c|}{ ] } \\
\hline Fuji & $484 \mathrm{a}^{2}$ & $458 \mathrm{a}$ & $51 \mathrm{a}$ & $726 \mathrm{~b}$ \\
\hline Gala & $213 \mathrm{a}$ & $344 \mathrm{a}$ & $50 \mathrm{a}$ & $1558 \mathrm{a}$ \\
\hline \multicolumn{5}{|l|}{ Rootstock } \\
\hline M.9 & nd & $392 \mathrm{a}$ & $31 \mathrm{~b}$ & $620 \mathrm{~b}$ \\
\hline MM.111 & nd & $411 \mathrm{a}$ & $70 \mathrm{a}$ & $1664 \mathrm{a}$ \\
\hline Main effects & \multicolumn{4}{|c|}{$(P>f)$} \\
\hline Scion $(\mathrm{S})$ & 0.19 & 0.11 & 0.94 & 0.01 \\
\hline Rootstock (R) & $\mathrm{nd}^{3}$ & 0.78 & 0.01 & 0.01 \\
\hline $\mathrm{S} \times \mathrm{R}$ & nd & 0.10 & 0.67 & 0.01 \\
\hline Treatments & \multicolumn{4}{|c|}{ Transpiration rate $\left(\mathrm{mmol} \mathrm{H}_{2} \mathrm{O} \mathrm{m}^{-2} \mathrm{~s}^{-1}\right)$} \\
\hline \multicolumn{5}{|c|}{ 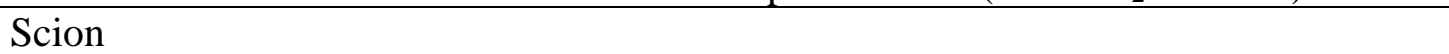 } \\
\hline Fuji & $2.2 \mathrm{a}$ & $4.0 \mathrm{a}$ & $1.2 \mathrm{a}$ & $4.9 \mathrm{a}$ \\
\hline Gala & $3.5 \mathrm{a}$ & $3.3 \mathrm{~b}$ & $1.1 \mathrm{a}$ & $5.3 \mathrm{a}$ \\
\hline \multicolumn{5}{|l|}{ Rootstock } \\
\hline M.9 & $4.3 \mathrm{a}$ & $3.8 \mathrm{a}$ & $0.7 \mathrm{~b}$ & $4.4 \mathrm{~b}$ \\
\hline MM.111 & $1.4 \mathrm{~b}$ & $3.6 \mathrm{a}$ & $1.6 \mathrm{a}$ & $5.7 \mathrm{a}$ \\
\hline Main effects & \multicolumn{4}{|c|}{$(P>f)$} \\
\hline Scion $(\mathrm{S})$ & 0.06 & 0.03 & 0.86 & 0.05 \\
\hline Rootstock (R) & 0.01 & 0.52 & 0.01 & 0.01 \\
\hline $\mathrm{S} \times \mathrm{R}$ & 0.05 & 0.07 & 0.99 & 0.25 \\
\hline
\end{tabular}

\footnotetext{
${ }^{1}$ Water was withheld until day 8 and then trees were watered daily.

${ }^{2}$ Within each day and main effect, mean values followed by the same letter do not differ at the 0.05 level of significance.

${ }^{3}$ nd designates no data.
} 
Table 2.

Main Effects of two scions ('Fuji' and 'Gala') and two rootstocks (M.9 and MM.111) during drought on leaf water use efficiency (WUE) ${ }^{1}$ and $\mathrm{CO}_{2}$ assimilation at noon measured in the greenhouse during 2014.

\begin{tabular}{|c|c|c|c|c|}
\hline \multirow[t]{3}{*}{ Treatments } & \multicolumn{4}{|c|}{ Days $^{2}$} \\
\hline & 1 & 4 & 7 & 14 \\
\hline & \multicolumn{4}{|c|}{ WUE $\left(\mu \mathrm{mol} \mathrm{CO} \mathrm{Cm}^{-2} \mathrm{~s}^{-1}\right) /\left(\mathrm{mmol} \mathrm{H}_{2} \mathrm{O} \mathrm{m} \mathrm{m}^{-2} \mathrm{~s}^{-1}\right)$} \\
\hline \multicolumn{5}{|l|}{ Scion } \\
\hline Fuji & $19.7 \mathrm{a}^{3}$ & $4.0 \mathrm{a}$ & $4.5 \mathrm{a}$ & $4.0 \mathrm{a}$ \\
\hline Gala & $11.5 \mathrm{a}$ & $4.1 \mathrm{a}$ & $5.1 \mathrm{~b}$ & $4.2 \mathrm{a}$ \\
\hline \multicolumn{5}{|l|}{ Rootstock } \\
\hline M.9 & $14.0 \mathrm{a}$ & $4.2 \mathrm{a}$ & $6.7 \mathrm{a}$ & $4.9 \mathrm{a}$ \\
\hline MM.111 & $17.3 \mathrm{a}$ & $3.7 \mathrm{~b}$ & $2.7 \mathrm{~b}$ & $3.3 \mathrm{~b}$ \\
\hline Main effects & \multicolumn{4}{|c|}{$(P>f)$} \\
\hline Scion $(\mathrm{S})$ & 0.16 & 0.42 & 0.75 & 0.52 \\
\hline Rootstock (R) & 0.56 & 0.01 & 0.01 & 0.01 \\
\hline $\mathrm{S} \times \mathrm{R}$ & 0.38 & 0.38 & 0.99 & 0.18 \\
\hline Treatments & \multicolumn{4}{|c|}{$\mathrm{CO}_{2}$ assimilation rate $\left(\mu \mathrm{mol} \mathrm{m} \mathrm{s}^{-2}\right)$} \\
\hline \multicolumn{5}{|l|}{ Scion } \\
\hline Fuji & 30.9 a & $16.4 \mathrm{a}$ & $4.3 \mathrm{a}$ & $19.6 \mathrm{a}$ \\
\hline Gala & $28.3 \mathrm{a}$ & $03.6 \mathrm{~b}$ & $4.2 \mathrm{a}$ & $21.8 \mathrm{a}$ \\
\hline \multicolumn{5}{|l|}{ Rootstock } \\
\hline M.9 & $36.3 \mathrm{a}$ & $16.1 \mathrm{a}$ & $5.0 \mathrm{a}$ & $21.9 \mathrm{a}$ \\
\hline MM.111 & $22.9 \mathrm{~b}$ & $13.9 \mathrm{a}$ & $3.5 \mathrm{a}$ & $19.4 \mathrm{~b}$ \\
\hline$\underline{\text { Main effects }}$ & \multicolumn{4}{|c|}{$(P>f)$} \\
\hline Scion $(\mathrm{S})$ & 0.13 & 0.05 & 0.75 & 0.06 \\
\hline Rootstock (R) & 0.01 & 0.12 & 0.11 & 0.02 \\
\hline $\mathrm{S} \times \mathrm{R}$ & 0.68 & 0.2 & 0.48 & 0.47 \\
\hline \multirow{2}{*}{\multicolumn{5}{|c|}{$\begin{array}{l}{ }^{1} \mathrm{WUE}=\mathrm{CO}_{2} \text { assimilation rate }\left(\mu \mathrm{mol} \mathrm{m} \mathrm{m}^{-2} \mathrm{~s}^{-1}\right) / \text { Transpiration rate }\left(\mathrm{mmol} \mathrm{H}_{2} \mathrm{O} \mathrm{m}^{-2} \mathrm{~s}^{-1}\right) \\
{ }^{2} \text { Water was witheld until day } 8 \text { and then trees were watered daily. }\end{array}$}} \\
\hline & & & & \\
\hline \multicolumn{5}{|c|}{$\begin{array}{l}{ }^{3} \text { Within each day and main effect, mean values followed by the same letter do not differ at the } \\
0.05 \text { level of significance. }\end{array}$} \\
\hline
\end{tabular}


Table 3.

Dry weight distribution in two scions ('Fuji' and 'Gala') and two rootstocks (M.9 and MM.111) measured in the greenhouse during 2014.

\begin{tabular}{|c|c|c|c|c|c|c|c|c|c|}
\hline Scion & Rootstock & $\begin{array}{c}\text { Total } \\
(\mathrm{g})\end{array}$ & $\begin{array}{c}\text { Leaf } \\
(\%)\end{array}$ & $\begin{array}{c}\text { Branch } \\
(\%)\end{array}$ & $\begin{array}{c}\text { Trunk } \\
(\%)\end{array}$ & $\begin{array}{c}\text { Shank } \\
(\%)\end{array}$ & $\begin{array}{c}\text { Root } \\
(\%)\end{array}$ & $\begin{array}{l}\text { Root } \\
\text { Fine } \\
(\%) \\
\end{array}$ & $\begin{array}{c}\text { Root } \\
\text { Coarse } \\
(\%)\end{array}$ \\
\hline Fuji & M9 & $347.6 \mathrm{a}^{1}$ & $10.3 \mathrm{~b}$ & $12.8 \mathrm{ab}$ & $30.9 \mathrm{ab}$ & $40.0 \mathrm{a}$ & $6.0 \mathrm{~b}$ & $54.3 \mathrm{a}$ & $45.7 \mathrm{a}$ \\
\hline Gala & M9 & $272.5 \mathrm{~b}$ & $18.4 \mathrm{a}$ & $9.9 \mathrm{bc}$ & $27.2 \mathrm{~b}$ & $38.1 \mathrm{a}$ & $6.5 \mathrm{~b}$ & $56.3 \mathrm{a}$ & $43.7 \mathrm{a}$ \\
\hline Fuji & MM111 & $228.6 \mathrm{~b}$ & $12.0 \mathrm{~b}$ & $8.2 \mathrm{c}$ & $33.8 \mathrm{a}$ & $31.9 \mathrm{ab}$ & $14.1 \mathrm{a}$ & $48.8 \mathrm{a}$ & $51.2 \mathrm{a}$ \\
\hline Gala & MM111 & $260.0 \mathrm{~b}$ & $17.1 \mathrm{a}$ & $15.8 \mathrm{a}$ & $31.2 \mathrm{ab}$ & $25.6 \mathrm{~b}$ & $10.2 \mathrm{ab}$ & $47.7 \mathrm{a}$ & $52.3 \mathrm{a}$ \\
\hline \multicolumn{2}{|c|}{ Main effects } & \multicolumn{8}{|c|}{$(P>f)$} \\
\hline \multicolumn{2}{|l|}{ Scion } & 0.27 & 0.01 & 0.53 & 0.01 & 0.10 & 0.42 & 0.50 & 0.42 \\
\hline \multicolumn{2}{|c|}{ Rootstock } & 0.01 & 0.10 & 0.08 & 0.04 & 0.01 & 0.09 & 0.09 & 0.18 \\
\hline \multicolumn{2}{|l|}{$\mathrm{S} * \mathrm{R}$} & 0.02 & 0.72 & 0.01 & 0.01 & 0.19 & 0.72 & 0.69 & 0.85 \\
\hline
\end{tabular}

${ }^{1}$ Within each response variable, means followed by the same letter do not differ at the 0.05 level of significance. 
Table 4.

Whole tree leaf traits and root-to-shoot ratios that were based on different tree components measured in the greenhouse during 2014.

\begin{tabular}{|c|c|c|c|c|c|c|}
\hline \multirow[t]{2}{*}{ Scion } & \multirow[t]{2}{*}{ Rootstock } & \multicolumn{3}{|c|}{ Root-to-shoot ratios } & \multicolumn{2}{|c|}{ Leaves per tree } \\
\hline & & $\begin{array}{c}\text { Total } \\
\text { Weight }^{1} \\
(\mathrm{~g})\end{array}$ & $\begin{array}{c}\text { Without } \\
\text { Shank }^{2} \\
\text { (g) }\end{array}$ & $\begin{array}{c}\text { Root-to-leaf } \\
(\mathrm{g})\end{array}$ & $\begin{array}{l}\text { Area } \\
\left(\mathrm{cm}^{2}\right)\end{array}$ & Number \\
\hline Fuji & M9 & $0.85 \mathrm{a}^{4}$ & $0.11 \mathrm{~b}$ & $0.57 \mathrm{~b}$ & $8693 \mathrm{ab}$ & $449 \mathrm{ab}$ \\
\hline Gala & M9 & $0.80 \mathrm{ab}$ & $0.11 \mathrm{~b}$ & $0.36 \mathrm{~b}$ & $10566 \mathrm{a}$ & $560 \mathrm{a}$ \\
\hline Fuji & MM111 & $0.86 \mathrm{a}$ & $0.26 \mathrm{a}$ & $1.16 \mathrm{a}$ & $5757 \mathrm{~b}$ & $275 \mathrm{~b}$ \\
\hline Gala & MM111 & $0.56 \mathrm{~b}$ & $0.15 \mathrm{~b}$ & $0.60 \mathrm{~b}$ & $7106 \mathrm{~b}$ & $355 \mathrm{~b}$ \\
\hline
\end{tabular}

${ }^{1}$ Shank dw + Root dw / (Leaf dw + Branch dw + Trunk dw)

${ }^{2}$ Root dw / (Leaf dw + Branch dw + Trunk dw)

${ }^{3}$ Root dw / Leaf dw

${ }^{4}$ Within each response variable mean values followed by the same letter do not differ at the 0.05 level of significance. 
Table 5.

Stomatal conductance of two scions ('Fuji' and 'Gala') grafted to two rootstocks (M.9 and MM.111) and grown in two pot volumes under drought conditions for 5 weeks in the greenhouse during 2015.

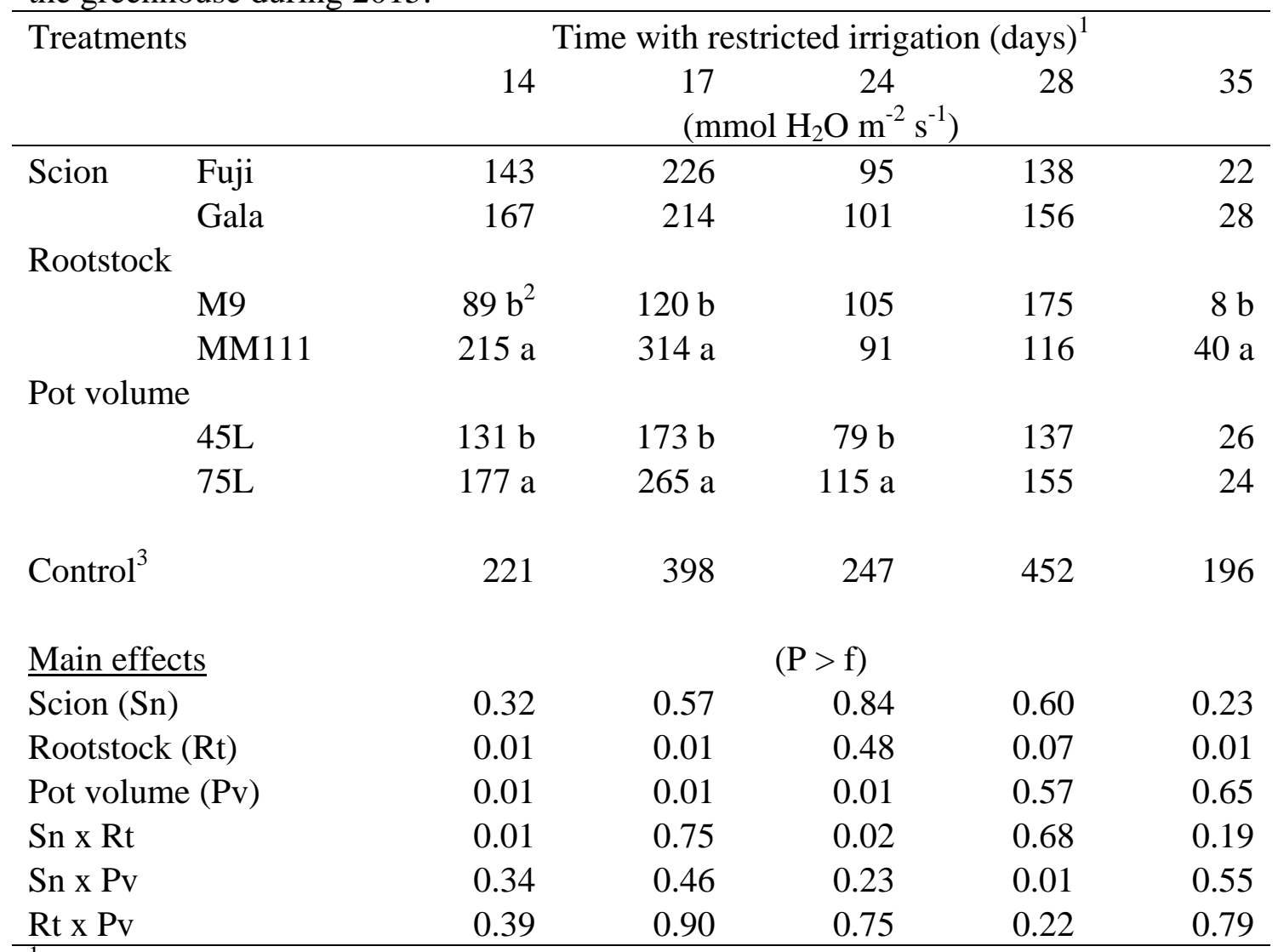

${ }^{1}$ Trees were grown with full water for 2 months and then water volumes were reduced to impose drought conditions. Data are presented for days 14 through 35 of restricted irrigation.

${ }^{2}$ Within each day and main effect, mean values followed by the same letter do not differ at the 0.05 level of significance.

${ }^{3}$ Well-watered pots averaged across scion and rootstock. 
Table 6.

Carbon assimilation of two scions ('Fuji' and 'Gala') grafted to two rootstocks (M.9 and MM.111) and grown in two pot volumes under drought conditions for 3 weeks in the greenhouse during 2015.

\begin{tabular}{|c|c|c|c|c|c|c|}
\hline \multicolumn{2}{|c|}{ Treatments } & \multicolumn{5}{|c|}{ Time with restricted irrigation (days) ${ }^{1}$} \\
\hline & & 14 & 17 & 24 & 28 & 35 \\
\hline & & \multicolumn{5}{|c|}{$\left(\mu \mathrm{mol} \mathrm{CO}_{2} \mathrm{~m}^{-2} \mathrm{~s}^{-1}\right)$} \\
\hline \multirow[t]{2}{*}{ Scion } & Fuji & 8.4 & 7.3 & 5.5 & 4.4 & 3.1 \\
\hline & Gala & 8.5 & 6.1 & 5.1 & 4.1 & 2.7 \\
\hline \multicolumn{7}{|c|}{ Rootstock } \\
\hline & M9 & $7.2 b^{2}$ & $4.9 \mathrm{~b}$ & 5.2 & 4.1 & $2.2 \mathrm{~b}$ \\
\hline & MM111 & $9.6 \mathrm{a}$ & $8.4 \mathrm{a}$ & 5.4 & 4.4 & $3.4 \mathrm{a}$ \\
\hline \multicolumn{7}{|c|}{ Pot volume } \\
\hline & $45 \mathrm{~L}$ & $7.7 \mathrm{~b}$ & $5.1 \mathrm{~b}$ & $4.6 \mathrm{~b}$ & 4.1 & 3.0 \\
\hline & $75 \mathrm{~L}$ & $9.1 \mathrm{a}$ & $8.1 \mathrm{a}$ & $6.0 \mathrm{a}$ & 4.4 & 2.8 \\
\hline \multicolumn{2}{|c|}{ Control $^{3}$} & 11.6 & 12.1 & 10.1 & 11.1 & 11.5 \\
\hline \multicolumn{2}{|c|}{$\underline{\text { Main effects }}$} & \multicolumn{5}{|c|}{$(P>f)$} \\
\hline \multicolumn{2}{|c|}{ Scion (Sn) } & 0.66 & 0.04 & 0.30 & 0.42 & 0.04 \\
\hline \multicolumn{2}{|c|}{ Rootstock (Rt) } & 0.01 & 0.01 & 0.64 & 0.39 & 0.01 \\
\hline \multicolumn{2}{|c|}{ Pot volume (Pv) } & 0.01 & 0.01 & 0.01 & 0.48 & 0.88 \\
\hline \multicolumn{2}{|c|}{ Sn $x$ Rt } & 0.01 & 1.00 & 0.27 & 0.15 & 0.01 \\
\hline \multicolumn{2}{|c|}{$\mathrm{Sn} \times \mathrm{Pv}$} & 0.09 & 0.04 & 0.36 & 0.95 & 0.31 \\
\hline \multicolumn{2}{|c|}{ Rt $x$ Pv } & 0.62 & 0.41 & 0.04 & 0.25 & 0.60 \\
\hline
\end{tabular}

${ }^{1}$ Trees were grown with full water for 2 months and then water volumes were reduced to impose drought conditions. Data are presented for days 14 through 35 of restricted irrigation.

${ }^{2}$ Within each day and main effect, mean values followed by the same letter do not differ at the 0.05 level of significance.

${ }^{3}$ Well-watered pots averaged across scion and rootstock. 
Table 7.

Water use efficiency of two scions ('Fuji' and 'Gala') grafted to two rootstocks (M.9 and MM.111) and grown in two pot volumes under drought conditions for 3 weeks in the greenhouse during 2015.

\begin{tabular}{|c|c|c|c|c|c|c|}
\hline \multicolumn{2}{|c|}{ Treatments } & \multicolumn{5}{|c|}{ Time with restricted irrigation (days) ${ }^{1}$} \\
\hline & & 14 & 17 & 24 & 28 & 35 \\
\hline & & \multicolumn{5}{|c|}{$\left(\mu \mathrm{mol} \mathrm{CO} \mathrm{CO}_{2} \mathrm{~m}^{-1}\right) /\left(\mathrm{mmol} \mathrm{H}_{2} \mathrm{O} \mathrm{m}^{-2} \mathrm{~s}^{-1}\right)$} \\
\hline \multirow[t]{2}{*}{ Scion } & Fuji & 4.6 & $3.2 \mathrm{a}^{2}$ & $6.4 \mathrm{a}$ & 5.2 & 5.4 \\
\hline & Gala & 4.3 & $2.3 \mathrm{~b}$ & $4.4 \mathrm{~b}$ & 4.0 & 8.8 \\
\hline \multicolumn{7}{|c|}{ Rootstock } \\
\hline & M9 & $5.2 \mathrm{a}$ & 2.6 & 5.1 & $5.6 \mathrm{a}$ & $9.2 \mathrm{a}$ \\
\hline & MM111 & $3.7 \mathrm{~b}$ & 2.8 & 5.8 & $3.7 \mathrm{~b}$ & $5.1 \mathrm{~b}$ \\
\hline \multicolumn{7}{|c|}{ Pot volume } \\
\hline & $45 \mathrm{~L}$ & 4.6 & $2.4 \mathrm{~b}$ & 5.0 & 4.1 & $9.7 \mathrm{a}$ \\
\hline & $75 \mathrm{~L}$ & 4.3 & $3.1 \mathrm{a}$ & 5.9 & 5.1 & $4.4 \mathrm{~b}$ \\
\hline Contro & & 4.6 & 3.8 & 5.1 & 5.2 & 5.8 \\
\hline \multicolumn{2}{|c|}{ Main effects } & \multicolumn{5}{|c|}{$(P>f)$} \\
\hline \multicolumn{2}{|c|}{ Scion (Sn) } & 0.54 & 0.01 & 0.01 & 0.13 & 0.07 \\
\hline \multicolumn{2}{|c|}{ Rootstock (Rt) } & 0.01 & 0.16 & 0.29 & 0.05 & 0.04 \\
\hline \multicolumn{2}{|c|}{ Pot volume (Pv) } & 0.28 & 0.01 & 0.22 & 0.21 & 0.02 \\
\hline \multicolumn{2}{|c|}{ Sn $x$ Rt } & 0.70 & 0.01 & 0.12 & 0.03 & 0.11 \\
\hline \multicolumn{2}{|c|}{$\mathrm{Sn} \times \mathrm{Pv}$} & 0.24 & 0.03 & 0.07 & 0.02 & 0.19 \\
\hline \multicolumn{2}{|c|}{ Rt x Pv } & 0.51 & 0.09 & 0.35 & 0.36 & 0.01 \\
\hline
\end{tabular}

${ }^{1}$ Trees were grown with full water for 2 months and then water volumes were reduced to impose drought conditions. Data are presented for days 14 through 35 of restricted irrigation.

${ }^{2}$ Within each day and main effect, mean values followed by the same letter do not differ at the 0.05 level of significance.

${ }^{3}$ Well-watered pots averaged across scion and rootstock. 
Table 8.

Leaf water potential (-MPa) of two scions ('Fuji' and 'Gala') grafted to two rootstocks (M.9 and MM.111) and grown in two pot volumes under drought conditions for 3 weeks in the greenhouse during 2015.

\begin{tabular}{|c|c|c|c|c|c|c|}
\hline \multirow{3}{*}{\multicolumn{2}{|c|}{ Treatments }} & \multicolumn{5}{|c|}{ Time with restricted irrigation (days) ${ }^{1}$} \\
\hline & & 14 & 17 & 24 & 28 & 35 \\
\hline & & \multicolumn{5}{|c|}{$(-\mathrm{MPa})$} \\
\hline \multirow[t]{2}{*}{ Scion } & Fuji & 1.7 & $1.8 \mathrm{~b}^{2}$ & $2.0 \mathrm{~b}$ & 1.8 & 2.3 \\
\hline & Gala & 1.7 & $2.0 \mathrm{a}$ & $2.2 \mathrm{a}$ & 1.7 & 2.3 \\
\hline \multicolumn{7}{|c|}{ Rootstock } \\
\hline & M9 & 1.8 & 2.0 & 2.0 & $2.0 \mathrm{a}$ & 2.3 \\
\hline & MM111 & 1.6 & 1.8 & 2.2 & $1.6 \mathrm{~b}$ & 2.3 \\
\hline \multicolumn{7}{|c|}{ Pot volume } \\
\hline & $45 \mathrm{~L}$ & $1.9 \mathrm{a}$ & $2.2 \mathrm{a}$ & $2.3 \mathrm{a}$ & 1.9 & $2.2 \mathrm{~b}$ \\
\hline & $75 \mathrm{~L}$ & $1.5 \mathrm{~b}$ & $1.6 \mathrm{~b}$ & $1.9 \mathrm{~b}$ & 1.7 & $2.4 \mathrm{a}$ \\
\hline \multicolumn{2}{|c|}{ Control $^{3}$} & 1.0 & 1.0 & 0.8 & 0.8 & 1.4 \\
\hline \multicolumn{2}{|c|}{ Main effects } & \multicolumn{5}{|c|}{$(P>f)$} \\
\hline \multicolumn{2}{|c|}{ Scion (Sn) } & 0.97 & 0.01 & 0.05 & 0.49 & 0.25 \\
\hline \multicolumn{2}{|c|}{ Rootstock (Rt) } & 0.20 & 0.08 & 0.21 & 0.01 & 0.32 \\
\hline \multicolumn{2}{|c|}{ Pot volume (Pv) } & 0.01 & 0.01 & 0.01 & 0.08 & 0.02 \\
\hline \multicolumn{2}{|c|}{ Sn $x$ Rt } & 0.59 & 0.03 & 0.21 & 0.01 & 0.50 \\
\hline \multicolumn{2}{|c|}{$\mathrm{Sn} \times \mathrm{PV}$} & 0.97 & 0.83 & 0.03 & 0.29 & 0.01 \\
\hline \multicolumn{2}{|c|}{ Rt $x$ Pv } & 0.43 & 0.11 & 0.53 & 0.05 & 0.06 \\
\hline
\end{tabular}

${ }^{1}$ Trees were grown with full water for 2 months and then water volumes were reduced to impose drought conditions. Data are presented for days 14 through 35 of restricted irrigation.

${ }^{2}$ Within each day and main effect, mean values followed by the same letter do not differ at the 0.05 level of significance.

${ }^{3}$ Well-watered pots averaged across scion and rootstock. 
Table 9.

Apparent root surface water potential (ARSWP) of two scions ('Fuji' and 'Gala') grafted to two rootstocks (M.9 and MM.111) and grown in two pot volumes under drought conditions for 3 weeks in the greenhouse during 2015.

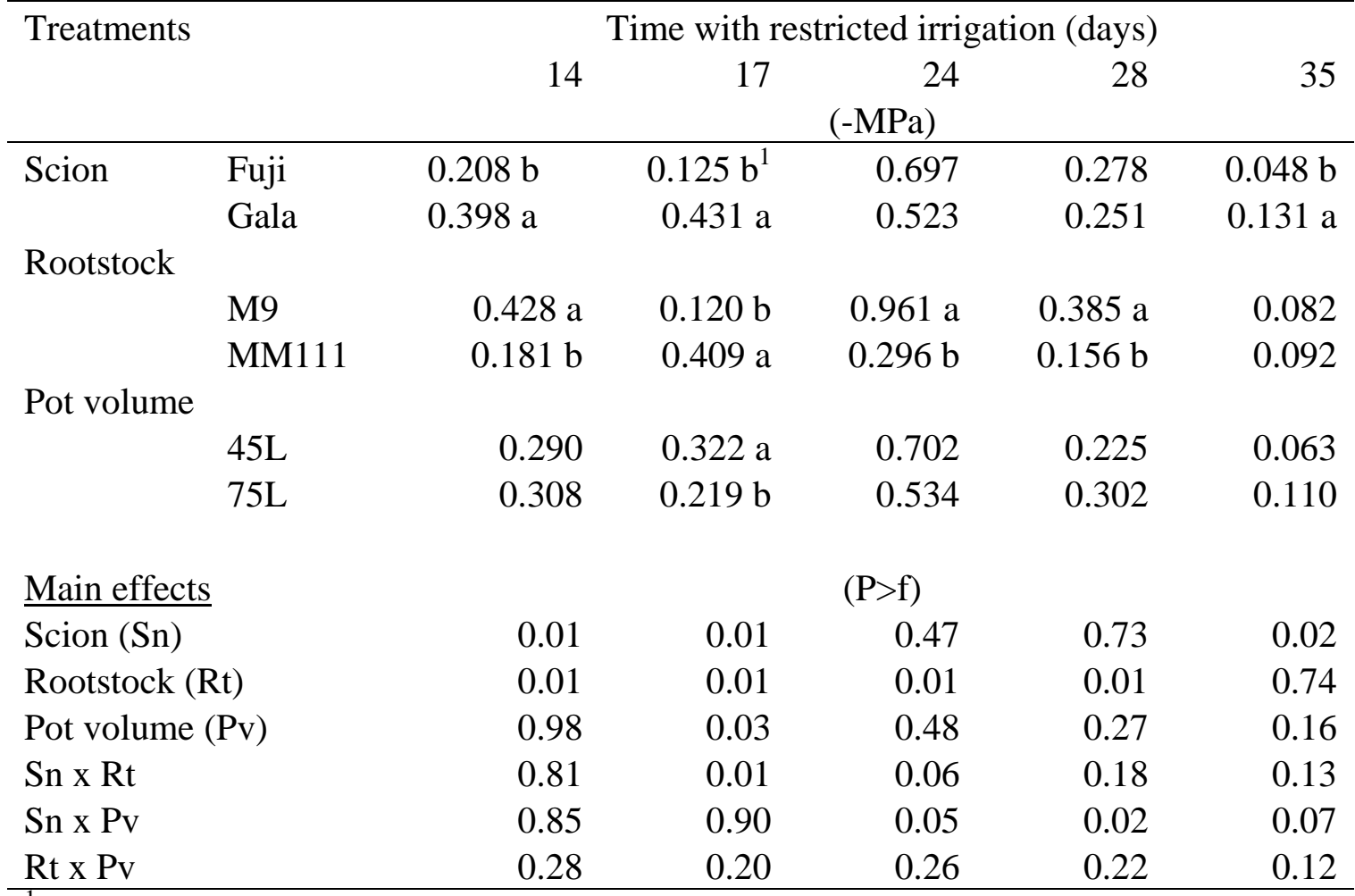

${ }^{1}$ Within each day and main effect, mean values followed by the same letter do not differ at the 0.05 level of significance. 


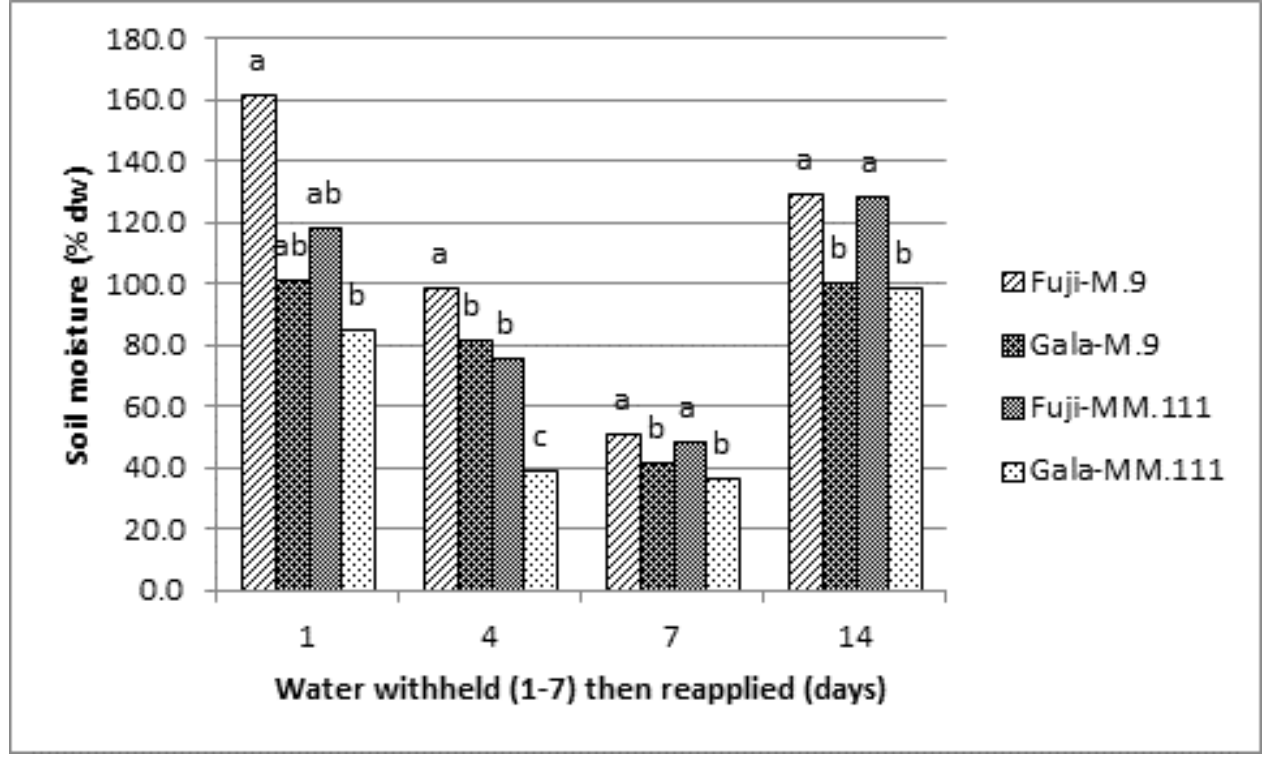

Fig. 1. Effect of drought and combinations of two scions ('Fuji' and 'Gala') and two rootstocks (M.9 and MM.111) on potting soil moisture measured in the greenhouse during 2014. Water was withheld from 1 to 7 days and reapplied from 7 to 14 days. Within each day bars with the same letter do not differ at the $0.05 \%$ level of significance. 


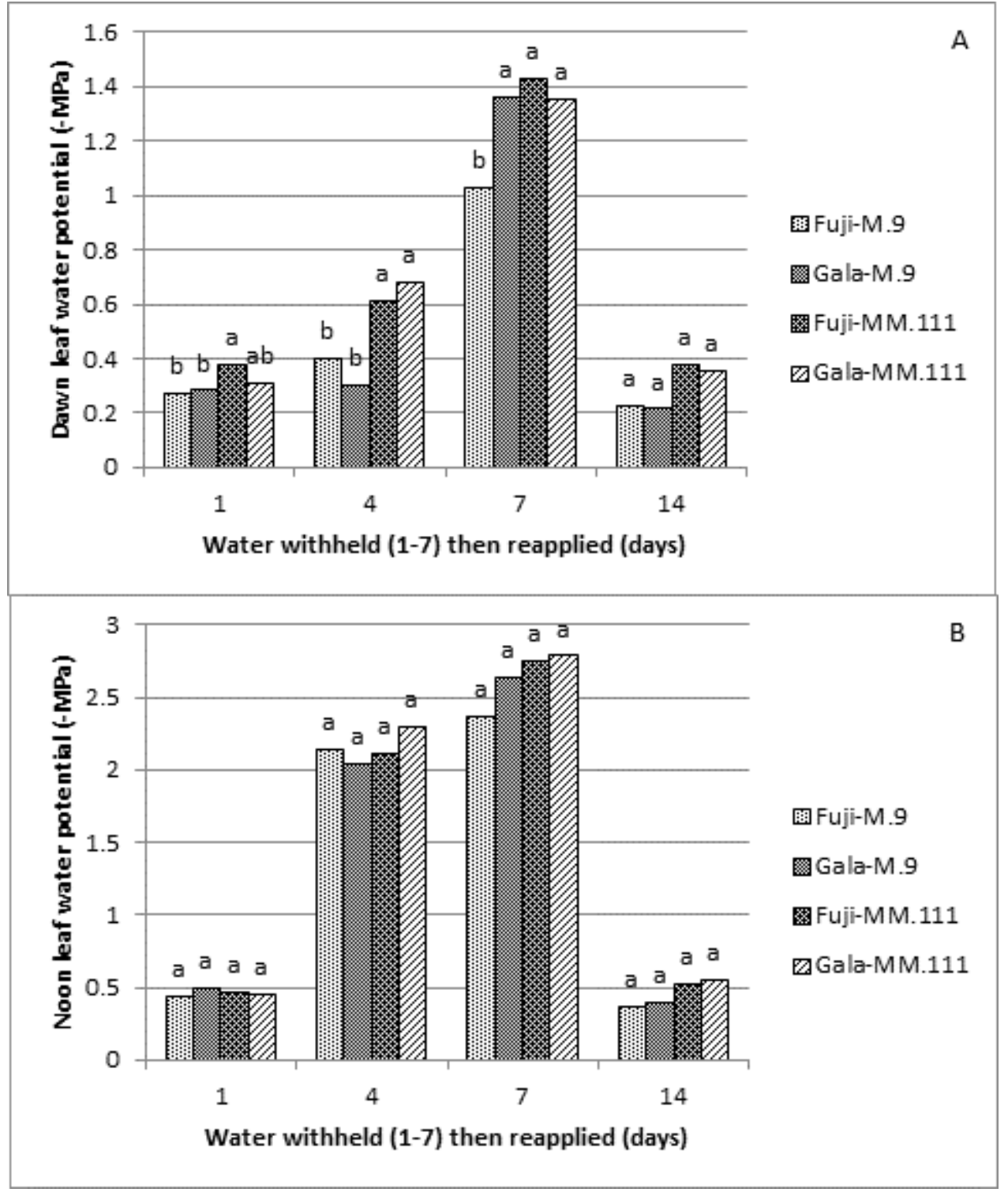

Fig. 2. Effect of drought and combinations of two scions ('Fuji' and 'Gala') and two rootstocks (M.9 and MM.111) on leaf water potential at dawn (top) and noon (bottom) measured in the greenhouse during 2014. Water was withheld from 1 to 7 days and reapplied from 7 to 14 days. Within each day bars with the same letter do not differ at the $0.05 \%$ level of significance. 


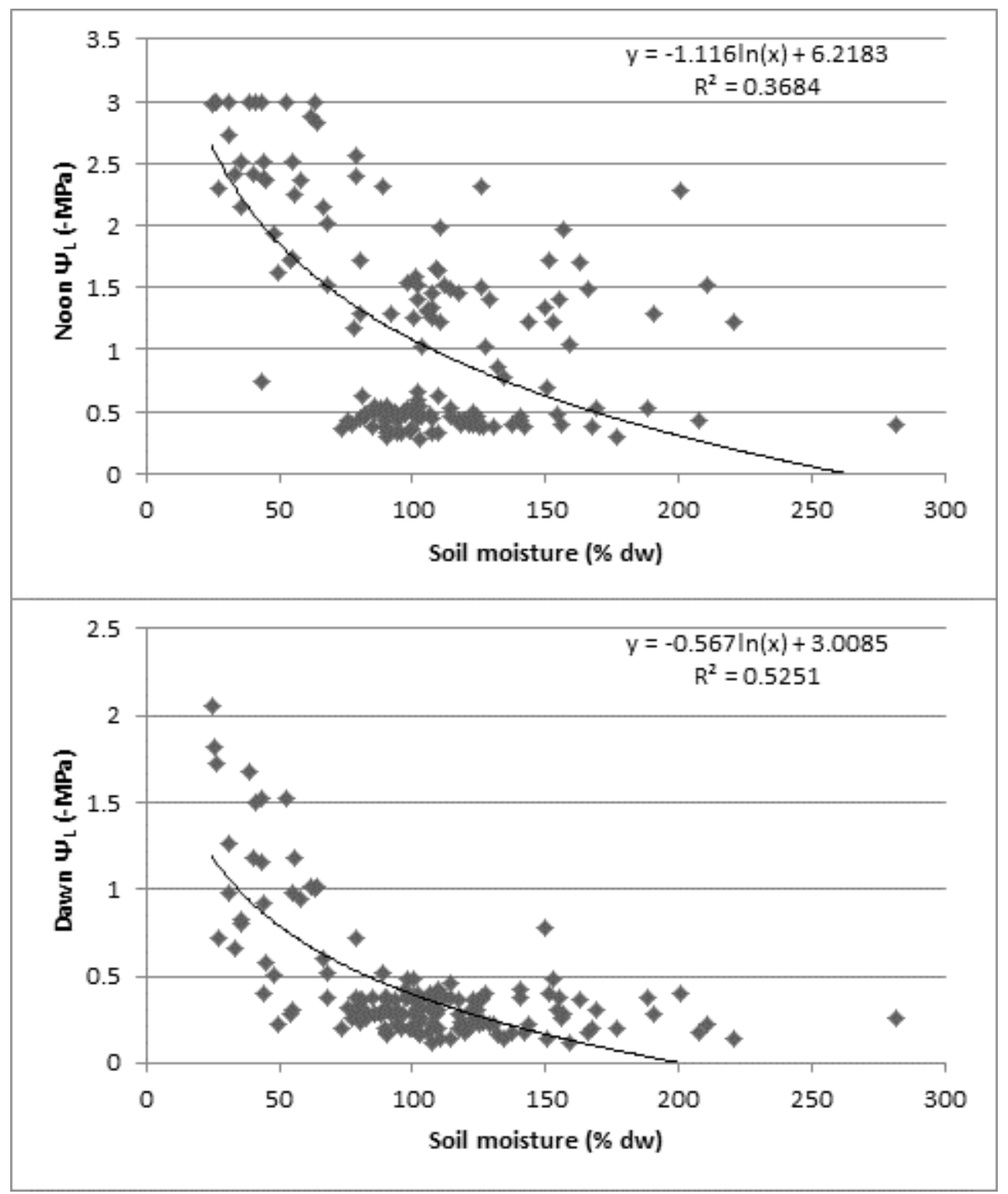

Fig. 3. Effect of water content of potting soil on leaf water potential at noon (top) and dawn (bottom) measured in the greenhouse during 2014. 


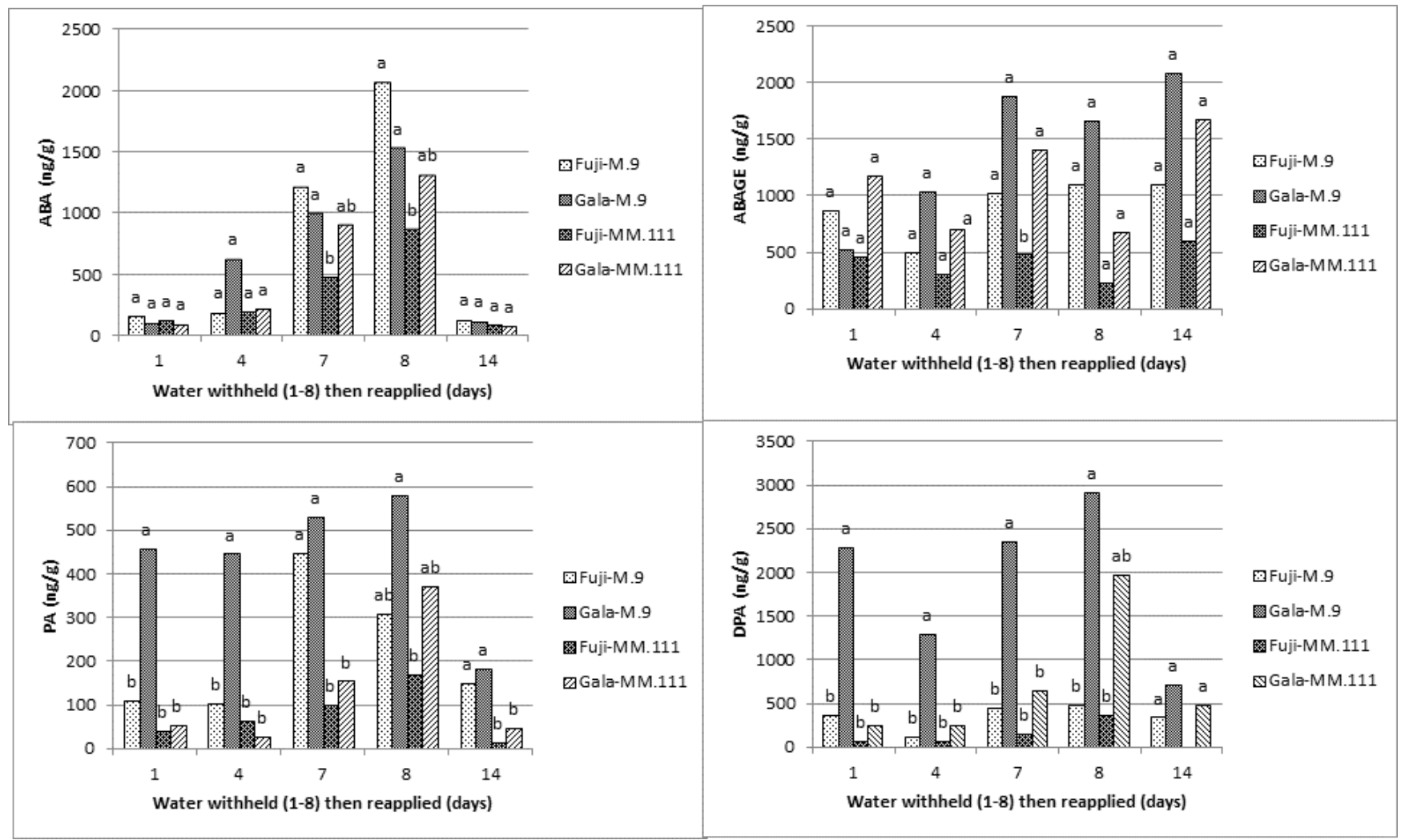

Fig. 4. Effect of drought on leaf endogenous levels of ABA and ABA-metabolites ABAGE (abscisic acid glucose ester), PA (phaseic acid) and DPA (dihydrophaseic acid), in two scions ('Fuji' and 'Gala') and two rootstocks (M.9 and MM.111) measured in the greenhouse during 2014. Water was withheld from 1 to 7 days and reapplied from 8 to 14 days. Within each day bars with the same letter do not differ at the $0.05 \%$ level of significance. 


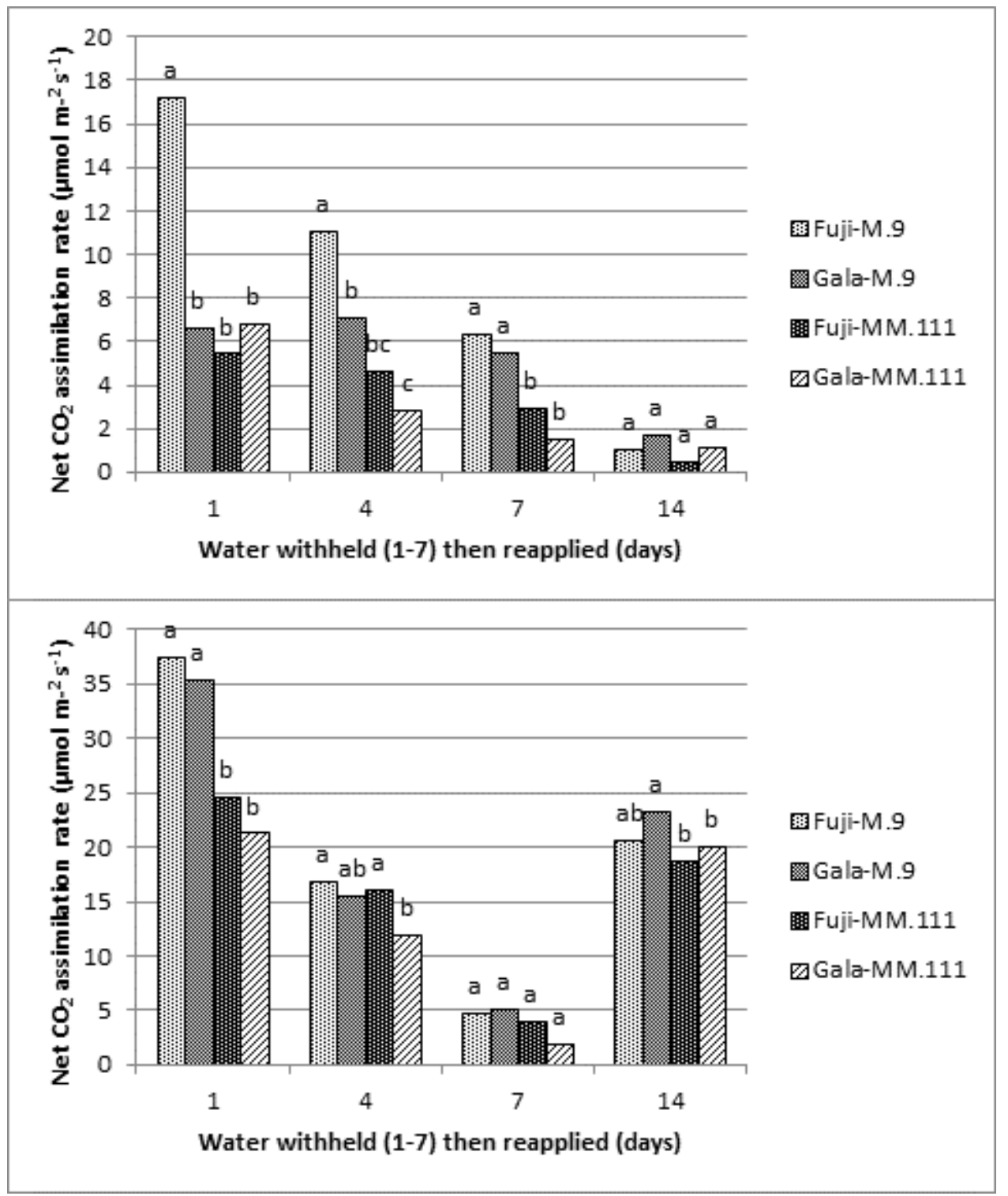

Fig. 5. Effect of drought and combinations of two scions ('Fuji' and 'Gala') and two rootstocks (M.9 and MM.111) on leaf assimilation rate potential at dawn (top) and noon (bottom) measured in the greenhouse during 2014. Water was withheld from 1 to 7 days and reapplied from 7 to 14 days. Within each day bars with the same letter do not differ at the $0.05 \%$ level of significance. 


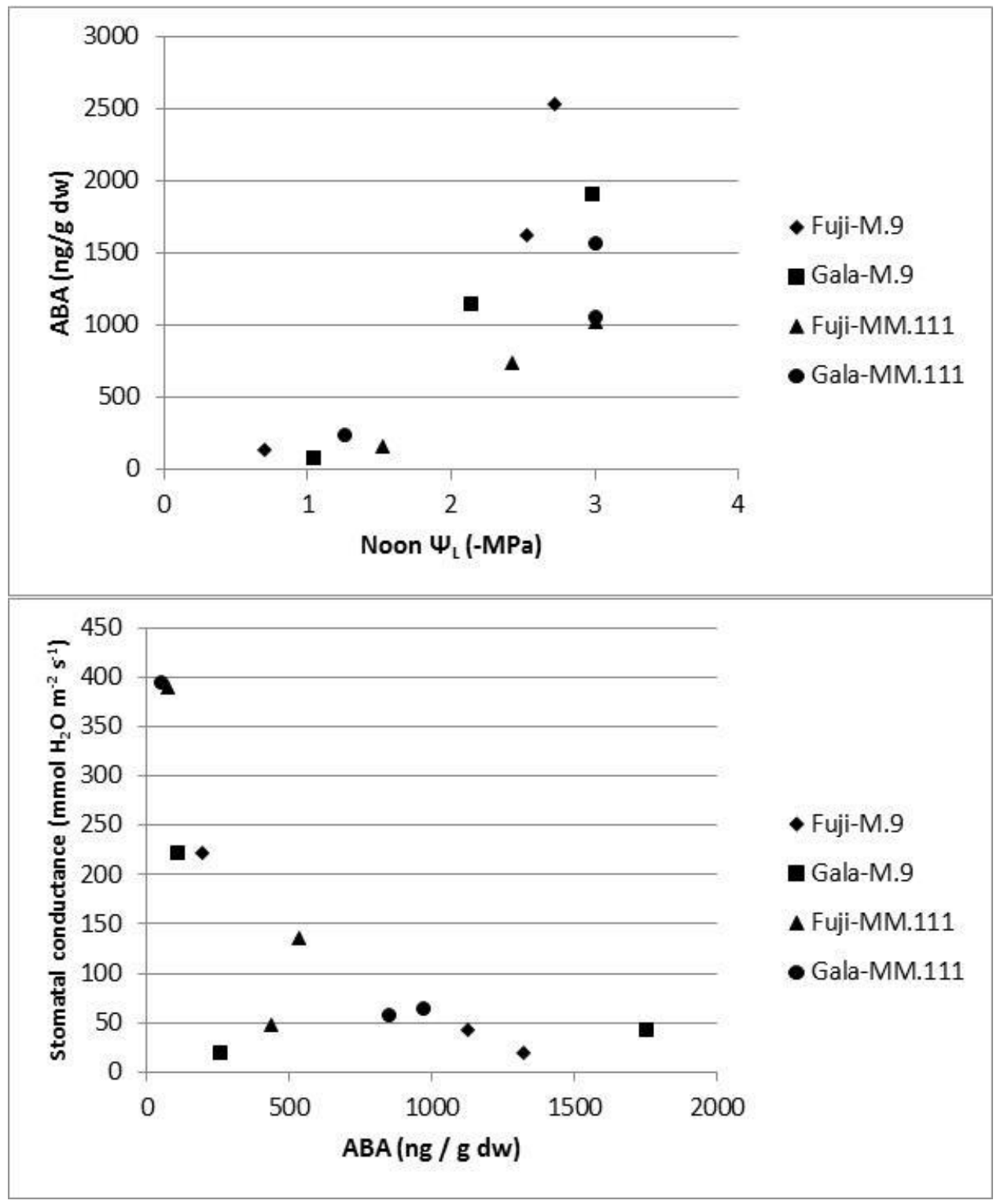

Fig. 6. Relationship of leaf water potential and ABA (top) and ABA and stomatal conductance (bottom) measured at noon after 7 days without irrigation in the greenhouse during 2014 . 